\title{
SISTEM AGRIBISNIS INTEGRASI PADI KERBAU DAN POLA PEMELIHARAAN KERBAU DI KECAMATAN PAMPANGAN SUMATERA SELATAN
}

\author{
Elly Rosana, Thirtawati*, Muhammad Arbi, Muhammad Ridwan \\ Program Studi Agribisnis, Fakultas Pertanian, Universitas Sriwijaya \\ Jl. Palembang-Prabumulih Km. 32 Indralaya, Ogan Ilir 30662 \\ *Corresponding author: thirtawati@unsri.ac.id
}

\begin{abstract}
This study aimed to determine and analyze the integrated rice-buffalo agribusiness system and to describe the pattern of buffalo raising in Pampangan District. This research was conducted in Pampangan District in July 2020. This research is a survey that took 30 samples purposively. Primary and secondary data obtained from the field survey were tabulated and analyzed descriptively-qualitatively. The integrated rice-buffalo agribusiness system in Pampangan District consists of the upstream subsystem, namely the provision of production facilities for rice-buffalo integration activities, the farming subsystem in the form of rice cultivation and livestock raising, the downstream subsystem, namely post-harvest and management of rice-buffalo waste used for organic fertilizer and silage. The supporting subsystem is that farmers have joined Gapoktan and have received training from BPTP on making compost. Raising buffalo in Pampangan District is still traditional, which is almost entirely relying on nature. The buffaloes are released in the morning and put back in the afternoon, allowed to eat the feed in the grazing environment. In contrast, for the health of the buffalo, it is still done as necessary and not as intensive. The profitsharing system between the owner and the custodian is known as the half system. The results of buffalo livestock production are obtained from the sale of buffalo and from the processing of buffalo milk production into sugar, sagon, curd or cow oil (a popular local term in Pampangan Sub-district).
\end{abstract}

Keywords: agribusiness systems, buffalo breeding patterns, rice-buffalo integration

Abstrak: Tujuan penelitian ini untuk mengetahui dan menganalisis sistem agribisnis
integrasi padi-kerbau serta mendeskripsikan pola pemeliharaan kerbau di Kecamatan
Pampangan. Penelitian ini dilaksanakan di Kecamatan Pampangan pada bulan Juli
2020. Penelitian ini merupakan survey yang mengambil 30 sampel secara purposif.
Data primer dan sekunder yang diperoleh dari survey lapangan ditabulasi dan
dianalisis secara deskriptif-kualitatif. Sistem agribinis integrasi padi-kerbau di
Kecamatan Pampangan terdiri dari subsistem hulu yaitu penyediaan sarana produksi
kegiatan integrasi padi-kerbau, subsistem usahatani berupa proses budidaya padi dan
pemeliharaan ternak, subsistem hilir yaitu pasca panen dan pengelolaan limbah padi-
kerbau yang dimanfaatkan untuk pupuk organik dan silase. Subsistem penunjang yaitu
petani sudah tergabung dalam Gapoktan dan sudah mendapatkan pelatihan dari BPTP
mengenai pembuatan pupuk kompos. Pola pemeliharaan ternak kerbau di Kecamatan
Pampangan masih bersifat tradisional yaitu dengan hampir sepenuhnya mengandalkan
alam. Kerbau dilepas pada pagi hari dan dimasukkan kembali sore hari, dibiarkan
memakan pakan yang ada di lingkungan penggembalaan, sementara untuk kesehatan
kerbau masih dilakukan seperlunya dan tidak intensif. Sistem bagi hasil antara pemilik
dan pemelihara dikenal sebagai sistem paroan. Hasil produksi ternak kerbau didapat 
dari penjualan kerbau dan dari hasil olah produksi susu kerbau menjadi gula puan, sagon, dadih atau minyak sapi (istilah lokal yang popular di Kecamatan Pampangan).

Kata kunci: sistem agribisnis, pola pemeliharaan kerbau, integrasi padi kerbau

\section{PENDAHULUAN}

Kerbau Pampangan merupakan ternak kerbau rawa yang khas ada di Sumatera Selatan, tepatnya berada di Kecamatan Pampangan. Yang merupakan merupakan salah satu kekayaan plasma nutfah di Provinsi Sumatera Selatan. Hasil produksinya selain daging, juga menghasilkan susu, yang bisa diolah menjadi berbagai olahan makanan. Karakteristik morfologis kerbau pampangan di Sumatera Selatan adalah warna bulu hitam/hitam keabuabuan, bentuk tubuh besar, temperamen tenang, kepala besar dan telinga panjang, tanduk ada yang tegak panjang dan melingkar ke arah belakang dan ada juga yang arah ke bawah. Bentuk ambing simetris dan berkembang dengan baik. Bobot badan rata-rata untuk jantan dewasa 400-450 kg dan betina dewasa 300-350 kg. Bentuk tanduk melingkar ke arah bawah atau menggantung, diduga karena telah terjadi inbreeding pada kerbau Pampangan (Muhakka et al., 2013).

Kecamatan Pampangan merupakan salah satu kecamatan yang terdapat di Kabupaten Ogan Komering Ilir Sumatera Selatan. Sebagian besar penduduknya memiliki mata pencaharian di bidang pertanian padi rawa lebak dan kerbau. Kedua komoditi ini menjadi komoditi utama yang ada di Kecamatan Pampangan. Berdasarkan Monografi Desa Kecamatan Pampangan tahun 2014, Kecamatan Pampangan memiliki 22 desa yang sebagian besar memiliki usaha di bidang pertanian padi dan kerbau pampangan. Untuk jumlah produksi komoditi padi rawa lebak rata-rata sebesar 600 ton per tahun dengan luas panen 150 hektar. Sedangkan, populasi kerbau pampangan sebanyak 3.476 ekor.

Mata pencarian masyarakat sebagai petani padi rawa lebak dan tidak terlepas dari kepemilikannya terhadap kerbau pampangan. Baik sebagai pemilik mau pun sebagai pemelihara. Di Kecamatan Pampangan sudah dicoba menggunakan sistem integrasi tanaman ternak (SITT) yang merupakan sistem usahatani dengan komponen ternak dan tanaman sebagai bagian utama kegiatan usaha yang mempunyai keterkaitan antara kedua komponen ini menghasilkan hubungan yang saling menguntungkan. Sistem integrasi tanaman-ternak di Kecamatan Pampangan mempunyai beberapa komponen yaitu budidaya tanaman padi, ternak kerbau dan pengelolaan limbah pertanian (jerami dan kompos) menjadi suatu produk yang bermanfaat bagi petani dan lingkungannya.

Ketika terjadi perubahan iklim, pertanian terintegrasi dapat digunakan untuk mitigasi pendapatan melalui beragam kegiatan pertanian tanaman-ternak terpadu. Pertanian terintegrasi dapat menjadi strategi ekonomis untuk mempertahankan hidup rumah tangga petani. Sistem integrasi padi-ternak memberikan keuntungan kepada petani yaitu pupuk kandang sapi dan bahan ikutan pertanian (by-product) berupa jerami dan dedak (Munandar et al., 2015). Pupuk kandang sapi selama ini belum optimal digunakan dapat dimanfaatkan sebagai pupuk organik untuk meningkatkan kesuburan tanah atau dapat dijual sebagai sumber pendapatan. Limbah pertanian yang tersedia dapat dimanfaatkan sebagai sumber pakan yang berkualitas, sehingga mengurangi biaya penyediaan pakan (Basuni et al., 2010). Lemaire et al. (2013) mengatakan integrasi tanaman-ternak selain mampu meningkatkan keragaman output produksi, juga mampu membuat regulasi siklus biogeokimia menjadi lebih baik, meningkatkan keragaman input dan habitat, dan meningkatkan kemampuan sistem untuk mengatasi potensi perubahan iklim. Selain itu, Gil et al. (2015) menyatakan bahwa adopsi teknologi integrasi tanaman-ternak masih rendah karena pengaruh aspek budaya lokal dan kurangnya penyebaran diseminasi teknologi. Pemberian kredit dianggap belum relevan untuk meningkatkan adopsi teknologi jika tidak disertai dengan pengetahuan budaya lokal dan penyebaran diseminasi yang lebih luas.

Sistem integrasi tanaman ternak (SITT) mulai diadopsi oleh petani di Kecamatan Pampangan sejak tahun 2015. Meskipun sudah cukup lama mengadopsi sistem ini, para petani tetap mengalami beberapa kesulitan yang 
mengakibatkan tidak berjalannya sistem ini dengan baik khususnya di bagian hilir. Jika dilihat dari keuntungan yang diperoleh dengan menggunakan sistem integrasi padi-ternak, peneliti tertarik untuk menganalisis bagaimana sistem agribisnis integrasi padi-kerbau dan mendeskripsikan pola pemeliharaan kerbau yang ada di Kecamatan Pampangan.

\section{METODE PENELITIAN}

Penelitian ini dilaksanakan di Kecamatan Pampangan, tepatnya di Desa Pulau Layang dan Desa Bangsal. Pemilihan lokasi ini dilakukan secara sengaja (purposive) berdasarkan pertimbangan bahwa Kecamatan Pampangan merupakan sentra pengembangan kerbau rawa dan penghasil padi rawa. Penelitian ini dilakukan pada bulan Juli 2020 dengan metode survey. Metode survei merupakan metode yang dilakukan dengan cara mengambil sebagian besar sampel dari populasi serta melakukan wawancara langsung dengan berpedoman kepada daftar pertanyaan atau kuesioner yang telah disiapkan. Metode penarikan contoh yang digunakan dalam penelitian ini adalah purposive sampling yaitu pengambilan sample secara sengaja dengan pertimbangan bahwa responden merupakan petani padi dan juga sebagai peternak kerbau, dengan jumlah responden 30 orang.

Data yang digunakan dalam penelitian ini berupa data primer dan data sekunder. Data primer diperoleh langsung di lapangan melalui survey, in depth interview, pengisian kuesioner, dan diskusi kelompok. Data sekunder diperoleh dari kantor kepala desa dan kecamatan, jurnal, dan dokumen-dokumen dari dinas-dinas terkait. Metode Pengumpulan data yang digunakan dalam penelitian ini adalah:

1. Observasi langsung yaitu pengamatan langsung obyek penelitian dengan tujuan untuk mendapatkan gambaran tentang system integrasi padi kerbau.
2. In depth interview yaitu komunikasi secara lisan yang terstruktur untuk menggali informasi.

3. Survei yaitu melalui kuesioner berisi daftar pernyataan yang ditujukan kepada pihakpihak terkait dengan topik penelitian.

4. Diskusi kelompok merupakan kegiatan diskusi dengan para stakeholder atau tokoh masyarakat dengan berbagai tema penelitian.

Data yang diperoleh dari hasil survei lapangan diolah secara tabulasi yang dilanjutkan dengan perhitungan matematis sesuai kebutuhan. Data yang dikumpulkan melalui kuesioner juga diperiksa ulang untuk tujuan validasi, selanjutnya dianalisis secara deskriptif dan kualitatif.

\section{HASIL DAN PEMBAHASAN}

\section{Karakterisitk Petani Contoh Umur Petani}

Umur merupakan salah satu faktor yang berpengaruh terhadap kegiatan pengelolaan usahatani. Petani yang umurnya relatif muda mempunyai kemampuan dan tenaga yang besar, sedangkan untuk petani umur yang relatif tua (tidak produktif) mempunyai keterbatasan dalam mengelola usahataninya. Karakteristik umur petani contoh di Kecamatan Pampangan dapat dilihat pada Tabel 1 yang menunjukkan bahwa umur petani contoh dibagi menjadi 2 kategori yaitu umur produktif dan umur tidak produktif. Petani contoh yang masuk kedalam umur produktif sebanyak 30 sampel atau besar 93,33\% dan petani contoh yang masuk ke kategori tidak produktif sebanyak 2 sampel atau sebesar 6,67\% dari keseluruhan sampel.

Berdasarkan hasil penelitian di lapangan dapat dilihat bahwa umur petani contoh termasuk dalam usia produktif untuk melakukan pekerjaan atau menjalankan usahanya, dengan demikian potensi tenaga kerja petani dalam kegiatan usahatani maupun ternak kerbau masih tinggi.

Tabel 1. Pengelompokan petani berdasarkan umur Kecamatan Pampangan tahun 2020

\begin{tabular}{cccc}
\hline No & Tingkat Umur (Tahun) & Jumlah (Orang) & Persentase (\%) \\
\hline 1. & $16-64$ (umur produktif) & 28 & 93,33 \\
2. & $>64$ (umur tidak produktif) & 2 & 6,67 \\
\hline & Jumlah & 30 & 100,00 \\
\hline
\end{tabular}

Sumber: Data Primer Diolah, 2020 
Rosana, E., Thirtawati, Arbi, M., Ridwan, M. : Sistem Agribisnis Integrasi Padi Kerbau...

Tabel 2. Komposisi petani contoh berdasar jumlah anggota keluarga Kecamatan Pampangan tahun 2020

\begin{tabular}{cccc}
\hline No & Jumlah Anggota Keluarga (Orang) & Jumlah (Orang) & Persentase (\%) \\
\hline 1. & $<2$ & 1 & 3,13 \\
2. & $2-5$ & 28 & 87,50 \\
3. & $>5$ & 3 & 9,37 \\
\hline & Jumlah & 30 & 100,00 \\
\hline
\end{tabular}

Sumber: Data Primer Diolah, 2020

Tabel 3. Komposisi petani contoh berdasarkan tingkat pendidikan di Kecamatan Pampangan Tahun 2020

\begin{tabular}{|c|c|c|c|}
\hline No & Tingkat Pendidikan & Jumlah (Orang) & Persentase (\%) \\
\hline 1. & SD & 18 & 56,25 \\
\hline 2. & SMP & 5 & 15,62 \\
\hline 3. & SMA/STM & 8 & 25,00 \\
\hline & Diploma/S-1 & 1 & 3,12 \\
\hline & Jumlah & 32 & 100,00 \\
\hline
\end{tabular}

Sumber: Data Primer Diolah, 2020

\section{Anggota Keluarga Petani}

Besar kecilnya anggota rumah tangga petani juga merupakan salah satu faktor yang menentukan baagaimana petani mengelola usahataninya. Petani dengan jumlah anggota keluarga yang besar biasanya merupakan sumber tenaga kerja bagi usahataninya sehingga tidak perlu untuk mengeluarkan biaya tambahan untuk pengelolaan usahatani. Jumlah anggota keluarga petani contoh secara keseluruhan beragam mulai dari dua orang sampai lima orang. Kelompok petani berdasarkan jumlah anggota keluarga dapat dilihat pada Tabel 2.

Berdasaran Tabel 2 menunjukkan bahwa jumlah anggota keluarga petani contoh yang paling dominan adalah 25 orang sebanyak 28 sampel atau sebesar 87,5\%. Untuk jumlah anggota keluarga $>2$ hanya terdapat 1 sampel dan sisanya 3 sampel dengan jumlah anggota keluarga sebanyak $<5$ orang atau sebesar $9,37 \%$ dari keseluruhan sampel.

\section{Tingkat Pendidikan Petani}

Pendidikan merupakan salah satu faktor yang cukup penting dalam mengelola suatu usahatani. Biasanya tingkat pendidikan menentukan penerapan teknologi dalam mengelola usahatani. Tingkat pendidikan petani contoh secara keseluruhan bervariasi mulai dari rendah sampai tinggi yaitu mulai dari SD, SMP, SMA/STM dan Sarjana. Tingkat pendidikan petani contoh dapat dilihat pada Tabel 3.

Berdasarkan Tabel 3. petani contoh yang memiliki tingkat pendidikan SD sebanyak 18 sampel atau sebesar 56,25\%, tingkat pendidikan SMP sebanyak 5 sampel atau sebesar 15,62\%, tingkat SMA/STM sebanyak 8 sampel atau sebesar $25 \%$ dan tingkat pendidikan Diploma/S1 hanya sebanyak 1 sampel atau sebesar 3,12\%. Mayoritas petani contoh berada pada tingkat pendidikan rendah, mereka masih menganggap bahwa usahatani maupun usaha ternak kerbau tidak perlu adanya pendidikan. Usahatani maupun usaha ternak kerbau yang dilakukan berdasarkan pengalaman yang sudah ada secara turun temurun.

\section{Luas Garapan Petani}

Luas lahan yang digunakan petani contoh untuk melakukan kegiatan usahatani sangat bervariasi. Perbedaan luas lahan yang diusahakan oleh petani contoh akan memengaruhi penerimaan dan pendapatan mereka. Luas lahan petani contoh dapat dilihat pada Tabel 4. Luas lahan yang dimiliki oleh petani contoh dengan luas garapan $<1$ hektar (Ha) sebanyak 14 sampel atau sebesar 46,7\%, sebanyak 15 sampel memiliki garapan sebesar 12 hektar (Ha) atau sebesar 50\% dan hanya 1 sampel yang memiliki luas lahan $>2$ hektar (Ha) atau sebesar 3,33\%. Berdasarkan hasil penelitian di lapangan, dapat kita simpulkan bahwa rata-rata luas garapan di Kecamatan Pampangan sebesar 1,33 hektar (Ha). Untuk status kepemilikan lahan, seluruh petani contoh memiliki lahan pertanian dari turun temurun milik orang tua mereka sejak dulu. 
Rosana, E., Thirtawati, Arbi, M., Ridwan, M. : Sistem Agribisnis Integrasi Padi Kerbau...

Tabel 4. Komposisi Petani Contoh Berdasarkan Luas Lahan Di Kecamatan Pampangan Tahun 2020

\begin{tabular}{cccc}
\hline No & Luas Lahan Garapan (Ha) & Jumlah (Orang) & Persentase (\%) \\
\hline 1. & $<1$ & 14 & 46,67 \\
2. & 12 & 15 & 50,00 \\
3. & 2 & 1 & 3,33 \\
\hline Rata-rata & 1,33 & 30 & 100,00 \\
Jumlah & & \multirow{2}{*}{30} \\
\hline
\end{tabular}

Sumber: Data Primer Diolah, 2020

Tabel 5. Komposisi Petani Contoh Berdasar Lama Berusahatani Padi di Kecamatan Pampangan Tahun 2020

\begin{tabular}{cccc}
\hline No & Lama Usahatani $(\mathrm{Th})$ & Jumlah (Orang) & Persentase (\%) \\
\hline 1. & $9-23$ & 14 & 46,67 \\
2. & $24-38$ & 11 & 36,67 \\
3. & $39-53$ & 5 & 16,67 \\
\hline Rata-rata & & 30 & 100,00 \\
Jumlah & & &
\end{tabular}

Sumber: Data Primer Diolah, 2020

Tabel 6. Komposisi Petani Contoh Berdasar Lama Beternak Kerbau di Kecamatan Pampangan Tahun 2020

\begin{tabular}{lccc}
\hline No & Lama Beternak Kerbau (Tahun) & Jumlah Petani Contoh & Persentase (\%) \\
\hline 1 & $1-13$ & 13 & 43,33 \\
2 & $14-27$ & 12 & 40,00 \\
3 & $28-41$ & 5 & 16,67 \\
\hline
\end{tabular}

Sumber: Data Primer diolah, 2020

\section{Lama Berusahatani Padi}

Lama berusahatani padi yang dilakukan oleh petani contoh dapat menunjukkan pengalaman petani itu sendiri. Pada umumnya usahatani padi telah lama dilakukan oleh petani contoh. Usahatani padi rawa lebak di Kecamatan Pampangan telah dilakukan secara turun temurun dan secara tradisional. Lama berusahatani yang dilakukan oleh petani contoh berada pada rentang waktu 9 tahun sampai 53 tahun. Lama berusahatani padi yang dilakukan oleh petani contoh dapat dilihat pada Tabel 5 . Lama berusahatani petani contoh terbanyak pada rentang waktu 9 sampai 23 tahun yaitu sebanyak 14 orang atau sebesar $46,67 \%$, lama berusahatani pada rentang waktu 24 sampai 38 tahun yaitu sebanyak 11 orang atau sebesar $36,67 \%$ dan untuk lama berusahatani paling rendah pada rentang waktu 39 sampai 53 tahun yaitu 5 orang atau sebesar 16,67\%.

\section{Lama Beternak Kerbau}

Pengalaman beternak kerbau merupakan salah satu faktor yang menentukan keberhasilan peternak dalam menjalankan usahanya. Semakin berpengalaman peternak maka semakin terampil peternak tersebut mengelolah usaha ternaknya. Pada umumnya usaha ternak kerbau sudah lama dilakukan oleh petani di
Kecamatan Pampangan. Lama berternak kerbau yang dilakukan oleh petani contoh dapat dilihat pada Tabel 5.

Pengalaman usaha ternak kerbau petani contoh terbanyak pada rentang waktu 1 sampai 13 tahun yaitu sebanyak 13orang atau sebesar 43,33\%. Semakin lama pengalaman beternak kerbau seseorang maka keterampilan yang dimiliki semakin tinggi. Walaupun usaha ternak kerbau telah dijalankan secara turun temurun, tetapi tidak terlihat keinginan peternak untuk mengembangkan usahanya secara ekonomis.

\section{Sistem Agribisnis Integrasi Padi-Kerbau di Kecamatan Pampangan}

Pembangunan ekonomi tidak lagi bertumpu pada sektor pertanian semata tetapi pada sistem agribinis. Paradigma lama hanya mengetengahkan bercocok tanam untuk petani (food producing) dan penangkapan serta budidaya untuk nelayan (food gathering and food producing). Sistem agribisnis akan melibatkan pertanian itu sendiri, agroindustri, pemasaran, dan jasa-jasa penunjang yang terkait, atau dengan kata lain sistem agribisnis telah berubah menjadi sistem manajemen agribisnis dengan penerapan fungsi-fungsi atau kegiatan manajemen (planning, organizing, 
directing, controlling, dan evaluation) pada setiap subsistem agribisnis mulai hulu sampai dengan hilir serta sektor penunjangnya (Astuti, 2017).

Secara umum konsep integrasi paditernak dalam usahatani tanaman baik perkebunan, pangan atau tanaman holtikultura adalah menempatkan dan mengusahakan sejumlah ternak, dalam hal ini ternak ruminansia (sapi, kerbau, domba, kambing) dan atau pseudoruminansia (kelinci, kuda) tanpa mengurangi aktivitas dan produkrivitas tanaman sekaligus produktivitas ternaknya (Direktorat Jenderal Peternakan, 2010). Kecamatan Pampangan mengadopsi sistem integrasi tanaman-ternak atau padi-kerbau rawa melalui Program BPTP (Balai Penelitian Teknologi Pangan) Sumatera Selatan.

Integrasi padi-kerbau rawa yang dimaksudkan oleh program ini adalah pemanfaatan sumberdaya yang berupa limbah produksi padi maupun limbah ternak kerbau yang dimanfaatkan oleh kedua sector tersebut guna mendapatkan manfaat untuk usahatani padi dan ternak kerbau rawa. Kecamatan Pampangan memiliki potensi yang besar dalam penyediaan bahan baku limbah baik limbah ternak kerbau maupun padi. Gambar 1 menjelaskan Integrasi padi-kerbau rawa tersebut.

Berdasarkan Gambar 1 dapat dilihat bahwa hubungan yang dibangun oleh ternak kerbau dan lahan sawah saling berkaitan dan berkelanjutan dimana kotoran kerbau diproses melalui rumah kompos menjadi pupuk oganik dan diberikan kepada lahan sawah begitupun sebaliknya limbah sawah yaitu jerami diproses di rumah kompos menjadi fermentasi jerami dan diberikan kepada kerbau.

Sistem ini merupakan simbiosis mutualisme yang saling menguntungkan bagi ternak maupun usahatani padi. Bukan hanya pemanfaatan limbah dari pertanian dan peternakan saja yang akan menjadi kelebihan dari sistem integrasi ini, dampak positif yang dirasakan petani juga hama burung akan berpindah kepada kerbau dimana burung akan memakan kutu yang ada di badan kerbau.

Agar sistem integrasi padi-kerbau ini dapat berkelanjutan, perlu dianalisis dari segi agribisnis. Hasil penelitian yang dilakukan (Matakena, 2017) di Kampung Wadio Distrik Nabire Barat mengenai keterkaitan subsistem agribisnis dengan usahatani komoditi jeruk manis menunjukkan bahwa sistem agribisnis terdiri subsistem input (hulu), subsistem produksi dan subsistem pengolahan (usaha tani), subsistem pemasaran hasil (hilir) dan sub sistem penunjang.

\section{Subsistem Agribisnis Hulu}

Balai Penelitian Teknologi Pangan (BPTP) merupakan subsistem hulu untuk kegiatan sistem integrasi padi-kerbau di Kecamatan Pampangan. BPTP memberi edukasi dan pelatihan cara pembuatan pupuk dan fermentasi jerami. BPTP juga memberikan bantuan fasilitas dalam pengembangan sistem integrasi ini seperti alat pencercah jerami, drum fermentasi jerami, membuat rumah kompos, memberikan beberapa cangkul, terpal dan activator untuk pembuatan pupuk organik di Kecamatan Pampangan.

\section{Subsistem Agribisnis Usaha Tani Padi dan Ternak Kerbau Budidaya Padi}

Komoditi padi menjadi komoditi utama di Kecamatan Pampangan sehingga merupakan pekerjaan utama yang dilakukan masyarakat setempat.

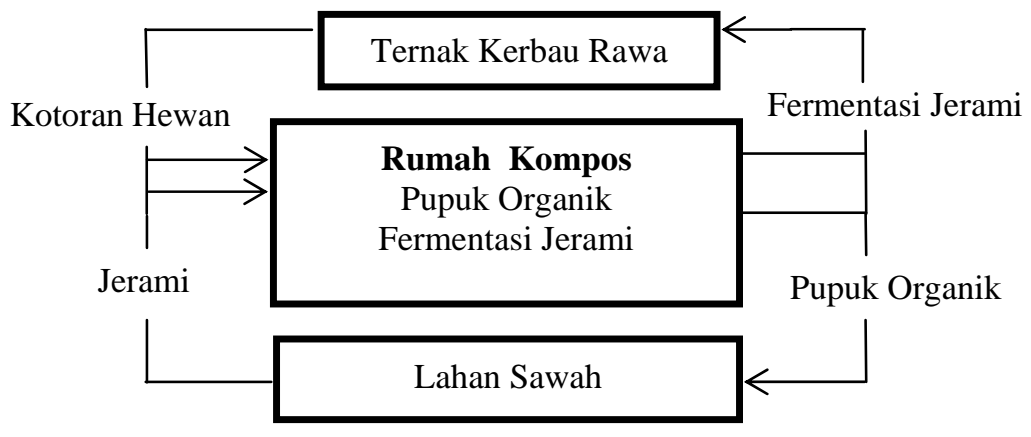

Gambar 1. Bagan integrasi padi-kerbau rawa 
Cara bertanam padi yang dilakukan petani masih tergolong konvensional dan memiliki 1 (satu) kali musim tanam karena kondisi lahan rawa lebak. Untuk proses budidayanya sendiri terdiri dari pembenihan, penyiapan lahan, penanaman, perawatan dan panen serta pasca panen. Hasil pasca panen inilah yang nanti akan diintegrasikan dengan perternakan yang ada di Kecamatan Pampangan.

\section{Pembenihan Padi}

Jenis benih yang biasa di pakai di Kecamatan Pampangan adalah Siarang, Beganti dan Inpara. Sebelum melakukan penyemaian, biasanya petani menyortir atau menyeleksi benih yang unggul agar mendapatkan hasil yang maksimal. Pada proses pembenihan diperlukan persiapan lahan tanam, dimana lahan diberi pupuk organik sebelum benih disebarkan.

\section{Penyiapan Lahan Sawah}

Persiapan lahan pada lahan rawa dapat dilakukan dengan sistem tanpa olah tanah atau TOT, lalu meninggikan dan memperbaiki pematang sawah yang telah rusak. Pengelolaan tanah di lahan sawah dilakukan sebelum awal musim tanam yaitu pada musim kemarau. Saat musim hujan di Kecamatan Pampangan belum bisa melakukan budidaya padi dikarenakan belum mempunyai teknologi yang mampu mendukung penanaman dimana lahan dalam kondisi terendam air. Sebelum dilakukan penanaman maka lahan diberi pupuk organic diberikan 3-7 hari sebelum tanam dengan dosis sebanyak 1,5 ton per hektarnya.

\section{Penanaman Padi}

Setelah tanah siap tanam dan benih yang disemaikan sudah tumbuh dengan umur sekitar 20-25 hari maka bibit sudah siap untuk di tanam di lahan sawah. Penanaman yang dilakukan oleh petani di Kecamatan Pampangan masih dilakukan dengan cara tradisional, menggunakan jarak tanam 20x20 $\mathrm{cm}$ antar bibit dan kedalaman penanaman kurang lebih $5 \mathrm{~cm}$ dari tanah.

\section{Perawatan padi}

Perawatan tanaman padi bertujuan untuk meningkatkan produksi padi melalui pemupukan, penyulaman, pembrantasan hama dan penyakit, penyiangan, dan pengairan.
Pemupukan dapat dilakukan ketika awal tanam dan ketika padi sudah masuk pada fase generative. Penyulaman tanaman dilakukan untuk menganti bibit tanaman padi yang mati ketika ditanam, penyulaman dilakukan maksimal 2 minggu setelah masa tanam. Sedangkan penyiangan dilakukan untuk menyingkirkan gulma dan tanaman liar lainnya yang ada di lahan.

\section{Panen dan Pasca Panen}

Tanaman padi rawa lebak dipanen tidak beda dengan panen padi sawah lainnya dengan melihat fisiologis dari padi, yang ditandai dengan bulir gabah yang telah berisi dan kulitnya sudah berwarna kekuningan serta saat butir gabah sudah menguning dan merunduk. Hasil panen dari budidaya ini sebagian besar dijual dalam bentuk gabah kering panen (GKP) karena lahan penjemuran padi tidak tersedia dengan baik dan mereka mengharapkan segera mednapatkan penghasilan. Sebagian hasil dijadikan persediaan untuk konsumsi bagi petani dan sisanya dijual. Limbah padi berupa jerami dibawa ke rumah kompos untuk dibuat fermentasi jerami untuk ternak kerbau.

\section{Ternak Kerbau}

Profesi sebagai peternak merupakan profesi yang didapatkan oleh sebagian besar masyarakat Kecamatan Pampangan secara turun temurun dari warisan orang tuanya dan program pemerintah 2016 memberikan 1 ekor kerbau kepada petani. Perternakan di Kecamatan Pampangan mempunyai kandang ternak yang tergabung di satu tempat sehingga mempermudah peternak mengiring dan mengontrol ternaknya. Untuk perawatan ternak sendiri dilakukan secara tradisional mulai dari pakan ternak yang berasal dari alam di sekitar Kecamatan Pampangan dan proses produksi yang dilakukan secara alamiah. Untuk pemasarannya, para peternak di Kecamatan Pampangan menjual kerbau hanya saat kebutuhan mendesak seperti sakit, biaya pendidikan, biaya pernikahan dan naik haji. Peternak lebih memanfaatkan susu kerbau sebagai mata pencaharian mereka. Susu kerbau diolah menjadi produk yang memiliki nilai tambah seperti gula puan, dadih dan sagon. 


\section{Subsistem Agribisnis Hilir}

Subsistem agribisnis hilir pada sistem integrasi padi-kerbau di Kecamatan Pampangan merupakan subsistem yang memiliki nilai ekonomi untuk para petani. Subsistem ini bermula dari pasca panen kemudian pengolaan limbah padi-kerbau. Limbah pertanian dan peternakan dapat dimanfaatkan secara optimal dengan menjadikan mereka kompos, pupuk serta pakan yang berupa fermentasi jerami. Adapun teknologi pengelolaan limbah yang telah dilakukan oleh Kecamatan Pampangan adalah sebagai berikut:

\section{Pembuatan Kompos Limbah Padi-Ternak}

Teknologi pembuataan kompos ini didapatkan oleh para petani dan peternak dari program BPTP. Proses pembuatan pupuk kompos yang ada di Kecamatan Pampangan terdiri dari 3 (tiga) tahap yaitu pertama persiapan bahan baku berupa jerami padi, kotoran kerbau, EM4 (EM diampur dengan gula merah) pertanian dan air. Kedua pencampuran bahan organik dengan cara diletakannya kotoran kerbau di lapisan paling bawah setinggi $20 \mathrm{~cm}$ dengan alas terpal kemudian limbah jerami diletakan di atas kotoran kerbau dan disiram dengan larutan EM4 dengan ukuran 30-40\% dari banyaknya limbah jerami dengan tinggi $20 \mathrm{~cm}$. Begitu seterusnya sampai 2 (dua) tumpukan dengan tinggi yang sama. Ketiga, penyelesain kompos dengan menutup tumpukan limbah dengan terpal dan dibalik dengan jangka waktu satu minggu. Proses pembalikan atau pengadukan dilakukan sebanyak 3 (tiga kali). Proses fermentasi ini berlangsung sekita 14-29 hari. Menurut peneliti BPTP-Balitbangtan Sumsel, kompos digunakan sebelum masa tanam dengan dosis $1 / 2$ ton untuk 1 hektarnya. Kelebihan dari larutan EM4 ini adalah dapat langsung digunakan dalam waktu yang relative singkat yaitu setelah proses 7-14 hari. Selain itu bokashi hasil pengomposan tidak panas, tidak berbau busuk, tidak mengandung hama dan penyakit, serta tidak membahayakan pertumbuhan atau produksi tanaman.

\section{Kompos Padat Kotoran Ternak}

Bahan utama dari pembuatan kompos kotoran ternak adalah kotoran sapi atau kerbau. BPTP juga telah mensosialisasikan dan memfasilitasi petani dan peternak Kecamatan Pampangan agar mampu memproduksi kompos padat kotoran kerbau. Proses pembuatan kompos padat ini sama dengan pembuatan kompos limbah padi-kerbau yaitu terdiri dari 3 (tiga) tahap. Pertama yaitu persiapan bahan baku berupa kotoran ternak, kapur, bioaktivator, abu sekam dan air. Kedua yaitu pencampuran bahan organik dengan cara kotoran ternak terlebih dahulu dikeringkan selama 1 (satu) minggu, kemudian dicampurkan bahan lainnya. Setelah diampur, kompos kemudian diperam selama seminggu dan diaduk. Untuk mengecek apakah bioaktivator aktif atau tidak yaitu dengan memasukan kayu/bambu kedalam kompos, apabila panas maka aktif begitupun sebaliknya. Pembuatan kompos padat ini memerlukan waktu selama 4 (empat) minggu dan setiap minggunya dilakukan pembalikan atau pengadukan.

Kompos padat kotoran ternak ini bukan hanya digunakan petani untuk memupuk tanamannya tapi juga dijadikan sebagai penghasilan tambahan yaitu dijual secara online yaitu melalui pengiklanan Kayuagung Expo dan Palembang Expo. Namun, untuk sekarang produksi dari pupuk organik ini belum dilakukan secara kontinue karena petani hanya membuat kompos padat saat ada pesananan saja.

\section{Fermentasi Jerami}

Limbah tanaman padi berupa jerami dapat dimanfaatkan menjadi pakan ternak dimana jerami difermentasikan dahulu di rumah kompos agar siap pakai. Fermentasi jerami bisa juga disebut silase merupakan pakan alternatif untuk ternak yang menjadi solusi dalam kelangkaan pakan dikarena lahan yang ada di sekitar Kecamatan Pampangan adalah lahan rawa lebak sehingga pada musim hujan maka lahan menjadi tergenang air dan pakan ternak akan menjadi langka, karena kurangnya pakan ternak merupakan salah satu factor menurunya populsi kerbau rawa, silase atau fermentasi jerami merupakan pakan alternatif yang menjadi solusi bagi masalah ini.

Proses fermantasi jerami terdiri dari 3 (tiga) tahap yaitu pertama penyiapan bahan berupa jerami, dedak, yakult dan air. Kedua, pencampuran bahan organik dengan ara memotong jerami sepanjang $5 \mathrm{~cm}$, kemudian mencampur semua bahan ke dalam drum yang sudah disiapkan. Ketiga, penyelesaian fermentasi jerami dengan menutup drum dan 
dibiarkan selama 4 (empat) minggu kemudian siap diberikan ke kerbau atau sapi.

Pengelolaan limbah padi-kerbau atau tanaman-ternak (integrasi) diharapkan mampu membantu para petani dan peternak dalam melanjutkan kegiatan usahatani mereka khususnya meningkatkan kesejahteraan mereka. Dengan adanya program ini dapat membantu untuk menambah nilai tambah dari limbah yang dahulunya dibiarkan atau dibuang, sekarang menjadi suatu produk yang bisa digunakan para petani peternak dan dijual ke luar daerah Kecamatan Pampangan.

\section{Subsistem Agribisnis Penunjang}

Subsistem penunjang merupakan hal yang penting bagi kelangsungan dan perkembangan sistem integrasi padi-kerbau sebagai suatu usaha atau produk yang bernilai ekonomi. Untuk peningkatan pendapatan petani sendiri belum ada pencatatan atau penelitian lebih lanjut mengenai penerapan sistem ini. Namun, para petani berada dalam naugan suatu kelompok tani dan berbentuk menjadi gabungan kelompok tani (Gapoktan) dari berbagai desa di Kecamatan Pampangan. Diharapkan dengan adanya Gapoktan dapat bekerjasama dengan pihak lainnya dalam pelaksanaanya dan dalam penjualanya produk rumah kompos sehingga mampu menyejahterakan petani karena limbah dari kerbau rawa yang sangat melimpah dan juga limbah dari pertanian padi yang di budidayakan petani cukup menjanjikan. Selain itu juga, terdapat pelatihan-pelatihan yang dilakukan oleh BPTP kepada masyarakat mengenai pembuatan pupuk kompos. Adanya program ini tidak terlempas dari permasalahanpermasalahan internal petani peternak sendiri seperti menurunnya motivasi dan kesadaran para petani peternak serta harga pupuk kimia yang cukup terjangkau membuat petani peternak di Kecamatan Pampangan malas untuk menjalankan integrasi tanaman ternak sehingga setelah program ini berjalan selama 2 (dua) tahun, terjadi penurunan produktivitas dari pengelolaan limbah padi-kerbau.

Pola Pemeliharaan Ternak Kerbau di Kecamatan Sistem Pemeliharaan Ternak Kerbau

Populasi ternak kerbau di Kecamatan Pampangan dari tahun ke tahun terus mengalami penurunan. Hal ini disebabkan karena sistem pemeliharaan yang dilakukan peternak masih tradisional, rendahnya kualitas pakan ternak, kurangnya modal dan rendahnya pengetahuan terhadap ilmu dan teknologi reproduksi kerbau karena perkembangan kerbau hanya dilakukan secara alami. Penurunan populasi kerbau ini sejalan dengan penelitian Perera (2011) yang menyatakan bahwa perkembangan populasi kerbau Pampangan di Sumatera Selatan dari 2010 hingga 2011 terjadi penurunan yaitu dari 76.113 menjadi 29.143 ekor (-61,7\%).

Cara pemeliharaan ternak kerbau di Kecamatan Pampangan disesuaikan dengan pola air rawa yaitu pada saat musim hujan dimana air pasang dan pada saat musim kemarau dimana air rawa kering. Pada saat musim hujan lahan penggembalaan digenangi air cukup tinggi dan rumput terapung untuk pakan kerbau banyak tersedia. Kondisi alam yang tergenang air cukup lama hampir sepanjang tahun membuat ternak kerbau dapat berenang. Para peternak melakukan penggembalaan kerbau pada saat musim hujan menggunakan perahu atau ketek. Pada saat musim kemarau saat air surut dan hanya beberapa bagian saja yang airnya dalam, sehingga rumput yang tumbuh terapung hanya tersedia sedikit sehingga pada musim kemarau kerbau secara berkelompok mencari makan hingga mencapai jarak yang cukup jauh. Menurut Komariah et al. (2014) keistimewaan kerbau dibandingkan ruminansia yang lain ialah mampu mencerna serat kasar yang tinggi sehingga kerbau mampu hidup di kawasan yang relatif sulit dengan kondisi pakan yang tersedia memiliki kualitas rendah, bahkan menurut Windusari et al. (2014) pertumbuhan kerbau dapat menyamai atau justru lebih baik dibandingkan sapi, dalam menghasilkan daging.

Pemeliharaan ternak kerbau di Kecamatan Pampangan dengan cara menggembala kerbau di lahan rawa dan pada saat malam hari kerbau beristirahat di kandang dengan kondisi leher terikat tali hal ini dilakukan agar kerbau tersebut tidak dicuri. Kerbau diturunkan atau dilepaskan dari kandang untuk mencari makan sejak pagi hari pukul 07.00 WIB dan digiring untuk kembali ke kandang pada sore hari pukul 17.00 WIB. Peran peternak sangat sederhana dan tidak 
terlalu sulit yaitu hanya sebatas mengontrol keberadaan kerbau, menjaga kesehatan kerbau dan menjaga hubungan antara peternak dan kerbau agar tetap dekat dan kerbau jinak. Kendala yang dihadapi peternak hanyalah sistem keamanan karena kerbau sering dicuri.

Ketersediaan pakan kerbau di Kecamatan Pampang cukup tinggi, rumput-rumput sangat banyak tersedia pada musim kemarau, namun pada saat musim hujan para peternak mengalami kelangkaan dalam penyediaan pakan ternak. Pemeliharaan kerbau rawa berbeda dengan kerbau atau sapi pada umumnya. Perbedaan utama terletak pada cara penggembalaan untuk mendapatkan pakan, peternak tidak memberi pakan baik hijaun maupun konsentrat, tetapi kerbau dibiarkan mencari makan sendiri. Pemeliharaan secara semi intensif pada sistem gaduhan ternak kerbau di Kecamatan Pampangan tidak begitu memerlukan perhatian khusus seperti pemeliharaan intensif. Pemeliharaan semi intensif lebih banyak mengambil waktu pada saat kerbau digembalakan daripada di dalam kandang, begitupun upaya pengendalian kerbau agar terhindar dari penyakit sangat sederhana dilakukan.

Pengendalian penyakit biasanya dilakukan dengan cara pengasapan yaitu membakar kotoran kerbau yang telah kering untuk menghilangkan nyamuk serta kutu yang menempel ditubuh kerbau. Selain itu peternak juga memberikan obat cacing, akan tetapi obat cacing yang diberikan sangat tidak rutin. Kerbau hanya diberikan obat cacing satu kali untuk jangka waktu yang sangat lama. Dengan demikian dari sisi pengendalian penyakit, para peternak sudah mampu melakukannya walaupun hanya dengan cara tradisional berdasarkan pengalaman dari nenek moyang.

\section{Sistem Perjanjian atau Bagi Hasil pada Sistem Gaduhan Ternak Kerbau di Kecamatan Pampangan}

Usaha ternak kerbau yang dilakukan oleh petani di Kecamatan Pampangan cukup unik yaitu dengan sistem gaduhan atau sistem bagi hasil sedangkan masyarakat sekitar menyebutnya dengan sistem "paroan”. Sistem gaduhan merupakan kerjasama dalam pemeliharaan kerbau antara pemilik ternak dan peternak Pemilik ternak menyediakan bakalan atau anak kerbau, kemudian pemilik ternak akan memberikan bakalan tersebut kepada peternak. Hasil usaha dibagi sesuai dengan kesepakatan bersama antara pemilik modal dan peternak. Sistem gaduhan ini sudah berlangsung sejak lama dan secara turun temurun. Pelaksanaan sistem gaduhan ternak kerbau dilakukan atas dasar saling kenal, saling percaya dan biasanya berdasarkan kekeluargaan.

\section{Hasil Produksi Ternak Kerbau}

Penerimaan yang diperoleh dari usaha sistem gaduhan ternak kerbau yaitu penjualan ternak dan nilai akhir ternak. Penjualan ternak di Kecamatan Pampangan hanya dilakukan sewaktu-waktu apabila ada kebutuhan keluarga yang sangat mendesak atau kebutuhan yang memerlukan uang dalam jumlah besar, misalnya biaya pendidikan anak, biaya membangun rumah, biaya membeli sawah, biaya modal dalam usahatani, biaya pergi haji, biaya berobat kerumah sakit, biaya membeli kendaraan dan biaya pernikahan anak. Sistem penjualan yang tidak rutin disebabkan karena pemeliharaan ternak kerbau oleh peternak bukan merupakan usaha pokok dengan tujuan budidaya, namun merupakan usaha sampingan. Tujuan utama masyarakat Kecamatan Pampangan hanya sebagai tambahan pendapatan dan sebagai tabungan.

Selain mendapatkan hasil berupa anak kerbau, peternak juga mendapatkan hasil produksi berupa susu kerbau. Susu tersebut dijual kepada pengumpul susu yang berada di Kecamatan Pampangan. Setiap pagi hari pengumpul susu datang ke kandang kerbau untuk membeli susu kerbau. Pengumpul susu inilah yang akan mengolah susu kerbau menjadi beberapa produk makanan seperti gula puan, sagon puan, dadih dan minyak sapi. Salah satu produk diberi nama minyak sapi oleh warga desa di Kecamatan ini, meskipun dihasilkan dari hasil susu kerbau bukan susu sapi. Sehingga sering dijadikan ungkapan oleh warga desa "kerbau punya susu sapi punya nama”. Minyak sapi ini seringkali digunakan sebagai campuran pembuatan makanan tradisional warga setempat, seperti bolu Palembang dan kue engkak yang umumnya dibuat pada saat-saat hari besar atau perayaan. Tetapi dari semua produk susu kerbau tersebut yang paling diminati yaitu gula puan, sehingga pengumpul susu biasanya memproduksi gula 
puan sebanyak 30 kilogram sampai 40 kilogram perminggunya. Untuk pemasaran biasanya pembeli langsung datang ke rumah pengrajin tetapi ada juga yang membawa langsung ke Kota Palembang untuk dipasarkan, tepatnya di Masjid Agung ketika hari Jumat.

\section{KESIMPULAN}

Sistem agribinis integrasi padi-kerbau di Kecamatan Pampangan terdiri dari subsistem hulu yaitu penyediaan sarana produksi kegiatan integrasi padi-kerbau, subsistem usahatani berupa proses budidaya padi dan pemeliharaan ternak, subsistem hilir yaitu pasca panen dan pengelolaan limbah padi-kerbau yang dijadikan suatu produk yang dapat dimanfaatkan untuk pupuk organik dan pakan ternak fermentasi (silase). Subsistem penunjang yaitu petani sudah tergabung dalam Gapoktan dan sudah mendapatkan pelatihan dari BPTP mengenai pembuatan pupuk kompos, hanya saja terdapat masalah dalam internal petani yang akhirnya program hanya berjalan efektif selama dua tahun. Dan setelahnya terjadi penurunan produksi.

Pola pemeliharaan ternak kerbau di Kecamatan Pampangan masih bersifat tradisional yaitu dengan sistem pemeliharaan yang hampir sepenuhnya mengandalkan alam. Dengan melepaskan kerbau pada pagi hari dan memasukkan kembali sore hari, kerbau dibiarkan memakan pakan yang ada di lingkungan penggembalaan, sementara untuk kesehatan kerbau masih dilakukan seperlunya dan tidak intensif. Sistem bagi hasil antara pemilik dan pemelihara dikenal sebagai sistem paroan. Dan terakhir untuk hasil produksi ternak kerbau didapat dari penjualan kerbau dan dari hasil olah produksi susu kerbau menjadi gula puan, sagon, dadih atau minyak sapi.

\section{DAFTAR PUSTAKA}

Astuti, D. R. D. (2017). Ekonomika Agribisnis (1st ed.). Makassar: Pusat Kegiatan Belajar Masyarakat Rumah Buku Carabaca.

\footnotetext{
Balitbangtan (Badan Penelitian dan Pengembangan Pertanian). (2011). Varietas Unggul Padi Untuk Rakyat
}

\author{
Mendukung Swasembada Beras \\ Berkelanjutan. Jakarta: Kementerian \\ Pertanian.
}

Basuni, R., Muladno, Kusmana, C., \& Suryahadi. (2010). Sistem integrasi padisapi potong di lahan sawah. Iptek Tanaman Pangan, 5(1), 31-48.

Direktorat Jenderal Peternakan. 2010. Pedoman Teknis Pengembangan Usaha Integrasi Ternak Sapi dan Tanaman. Jakarta: Direktorat Jenderal Peternakan Kementerian Pertanian.

Gil, J., Siebold, M., \& Berger, T. (2015). Adoption and development of integrated crop-livestock-forestry systems in Mato Grosso, Brazil. Agriculture, Ecosystems and Environment, 199, 394-406. https:// doi.org/10.1016/j.agee.2014.10.008.

Komariah, Kartiarso, \& Lita, M. (2014). Produktivitas kerbau rawa di Kecamatan Muara Muntai, Kabupaten Kutai Kartanegara, Kalimantan Timur. Buletin Peternakan, 38(3), 174-181. https://doi.o rg/10.21059/buletinpeternak.v38i3.5253.

Lemaire, G., Franzluebbers, A., Carvalho, P. C. de F., \& Dedieu, B. (2013). Integrated crop-livestock systems: Strategies to achieve synergy between agricultural production and environmental quality. Agriculture, Ecosystems and Environment, 190, 4-8. https://doi.org/ 10.1016/j.agee.2013.08.009.

Matakena, S. (2017). Agribisnis komoditi jeruk manis (Citrus Sinensis L) di Kampung Wadio Distrik Nabire Barat Kabupaten Nabire. Jurnal Fapertanak, II(1), 31-41.

Monografi Desa Kecamatan Pampangan. 2014. Profil Kecamatan Pampangan Kabupaten Ogan Komering Ilir 2014. BP3K: Kecamatan Pampangan.

Muhakka, M., Riswandi, R., \& M. Ali, A. I. (2013). Karakteristik morfologis dan reproduksi kerbau Pampangan di Propinsi Sumatera Selatan. Jurnal Sain Peternakan Indonesia, 8(2), 111-120. 
Rosana, E., Thirtawati, Arbi, M., Ridwan, M. : Sistem Agribisnis Integrasi Padi Kerbau...

https://doi.org/10.31186/jspi.id.8.2.111120.

Munandar, Gustiar, F., Yakup, Hayati, R., \& Munawar, A. I. (2015). Crop-cattle integrated farming system: An alternative of climatic change mitigation. Media Peternakan, 38(2), 95-103. https: //doi.org/10.5398/medpet.2015.38.2.95.

Perera, B. M. A. O. (2011). Reproductive cycles of buffalo. Animal Reproduction
Science, 124(3), 194-199. https://doi.org /10.1016/j.anireprosci.2010.08.022.

Windusari, Y., Nofyan, E., Kamal, M., Hanum, L. H., \& Pratama, R. (2014). Biophysic environmental conditions of swamp buffalo bubalus bubalis Pampangan in District Rambutan South Sumatera. Berkala Penelitian Hayati, 19(2), 78-81. https://doi.org/10.23869/bphjbr.19.2.201 47. 